\title{
Association of Phytophthora with Declining Vegetation in an Urban Forest Environment
}

\author{
Mohammed Y. Khdiar ${ }^{1,2}$, Paul A. Barber ${ }^{1,3}{ }^{\circledR}$, Giles E. StJ. Hardy ${ }^{1}{ }^{\circledR}$, Chris Shaw ${ }^{1}$, \\ Emma J. Steel ${ }^{1}{ }^{1}$, , Cameron McMains ${ }^{1}$ and Treena I. Burgess ${ }^{1, *}$ \\ 1 Phytophthora Science and Management, Centre for Climate Impacted Terrestrial Ecosystems, \\ Harry Butler Institute, Murdoch University, Murdoch 6150, Australia; moh_bio84@yahoo.com (M.Y.K.); \\ p.barber@arborcarbon.com.au (P.A.B.); g.hardy@murdoch.edu.au (G.E.S.H.); c.shaw@murdoch.edu.au (C.S.); \\ Emma.Steel@murdoch.edu.au (E.J.S.); Cameron.McMains@murdoch.edu.au (C.M.) \\ 2 Biology Department, Education College, Iraqi University, Adhamiya, Baghdad 7366, Iraq \\ 3 Arbor Carbon P/L, ROTA Compound off Discovery Way, Murdoch University, Murdoch 6150, Australia \\ * Correspondence: t.burgess@murdoch.edu.au
}

Received: 11 June 2020; Accepted: 26 June 2020; Published: 29 June 2020

check for updates

\begin{abstract}
Urban forests consist of various environments from intensely managed spaces to conservation areas and are often reservoirs of a diverse range of invasive pathogens due to their introduction through the nursery trade. Pathogens are likely to persist because the urban forest contains a mixture of native and exotic plant species, and the environmental conditions are often less than ideal for the trees. To test the impact of different land management approaches on the Phytophthora community, 236 discrete soil and root samples were collected from declining trees in 91 parks and nature reserves in Joondalup, Western Australia (WA). Sampling targeted an extensive variety of declining native trees and shrubs, from families known to be susceptible to Phytophthora. A sub-sample was set aside and DNA extracted for metabarcoding using Phytophthora-specific primers; the remaining soil and root sample was baited for the isolation of Phytophthora. We considered the effect on the Phytophthora community of park class and area, soil family, and the change in canopy cover or health as determined through sequential measurements using remote sensing. Of the 236 samples, baiting techniques detected Phytophthora species from 24 samples (18 parks), while metabarcoding detected Phytophthora from 168 samples (64 parks). Overall, forty-four Phytophthora phylotypes were detected. Considering only sampling sites where Phytophthora was detected, species richness averaged 5.82 (range 1-21) for samples and 9.23 (range 2-24) for parks. Phytophthora multivora was the most frequently found species followed by P. arenaria, P. amnicola and P. cinnamomi. While park area and canopy cover had a significant effect on Phytophthora community the $\mathrm{R}^{2}$ values were very low, indicating they have had little effect in shaping the community. Phytophthora cinnamomi and P. multivora, the two most invasive species, often co-occurring (61\% of samples); however, the communities with P. multivora were more common than those with P. cinnamomi, reflecting observations over the past decade of the increasing importance of $P$. multivora as a pathogen in the urban environment.
\end{abstract}

Keywords: metabarcoding; bridgehead effect; biological invasions; remote sensing

\section{Introduction}

The urban forest includes trees and shrubs in urban parks, road islands, woodlots, abandoned sites and residential areas [1,2]. Urban trees have been recognized to provide critical ecosystem services to human health and environmental quality, particularly with increasing urbanization [3]. However, urban forests through their mix of native and exotic trees [4], proximity to transport hubs [5] and tree nurseries [6], can provide a pathway for invasive pathogens to establish and move into 
natural ecosystems $[4,7]$. To prevent the dissemination of invasive species early detection, accurate identification and the ability to track pathogens back to their potential origin is essential [8].

The genus Phytophthora contains invasive pathogenic species responsible for tree diseases worldwide. The spread of Phytophthora species is a universal problem for nature preservation due to epidemics such as sudden oak death (USA), ramorum blight (UK), Phytophthora dieback (Australia) and Phytophthora root rot of Proteaceae (fynbos; South Africa). Within the urban forest, trees are under stress from polluting agents [9], mechanical damage, weeds, excess nutrients, climate change [10], and environmental factors such as waterlogging, salinity, flooding and drought $[11,12]$ therefore increasing their vulnerability to pathogens such as Phytophthora.

In recent years, numerous new Phytophthora species have been described, many of which include either the type isolate and/or additional isolates from an urban or disturbed ecosystem associated with the original description [13-15]. The isolation and identification of Phytophthora species can be difficult and time-consuming [16]. However, the use of species-specific primers to amplify target organisms for environmental DNA has made this more straight forward. Metabarcoding has been used for Phytophthora in natural ecosystems [17-19] and to a limited extent in urban environments $[14,16]$.

Perth, Western Australia (WA) is the most isolated and biodiverse city in the world [20]. Over the past three decades more than 17,000 hectares of vegetation have been cleared across the Perth metropolitan region [21]. Much of the native vegetation remaining in the region is susceptible to P. cinnamomi. One of the more recently developed areas north of Perth, the City of Joondalup, has many native Banksia woodland vegetation remnants. Remote sensing is a tool that can be used to monitor tree health in urban forests. It has been used to map Phytophthora and the distribution of the diseases they cause in different areas of the world [22-24]. Remotely sensed data acquired over four years, enabling changes in tree health to be determined, was utilized for our study. We field-validated the data by examining 236 declining groups of plants across 91 parks in the City's urban forest. The remote sensing data were also used to determine canopy cover. Rhizosphere soil and roots collected from the declining groups of plants were baited for Phytophthora species, and eDNA was extracted from a subsample and subject to metabarcoding using Phytophthora specific primers [17]. The Phytophthora community of the samples was examined to determine if it was influenced by canopy health, canopy cover, park area, park class or the soil family. Parks within the City tend to be either conservation areas, consisting of native plant species, or managed parks which contain a mix of native and exotic plant species and large areas of turf composed of exotic grass species. We hypothesized that Phytophthora communities would differ between conservation parks and those that were mostly turf.

\section{Materials and Methods}

\subsection{Study Area and Sample Collection}

The area investigated was the City of Joondalup, located approximately $26 \mathrm{~km}$ north of Perth, WA, covering an area of $98.9 \mathrm{~km}^{2}$ (Figure 1) and several different soil complexes. The Spearwood soil is a siliceous yellow sand, weakly acidic with some iron oxide $\left(0 \% \mathrm{CaCO}_{3}\right.$ to $120 \mathrm{~cm}$ depth) [25], the Quindalup soil is a calcareous whitish beach sand $\left(8-36 \% \mathrm{CaCO}_{3}\right)$, while the Karrakatta soil derived from calcareous beach sand $\left(50-70 \% \mathrm{CaCO}_{3}\right)$ leached to form secondary calcite layers at depth [26]. 


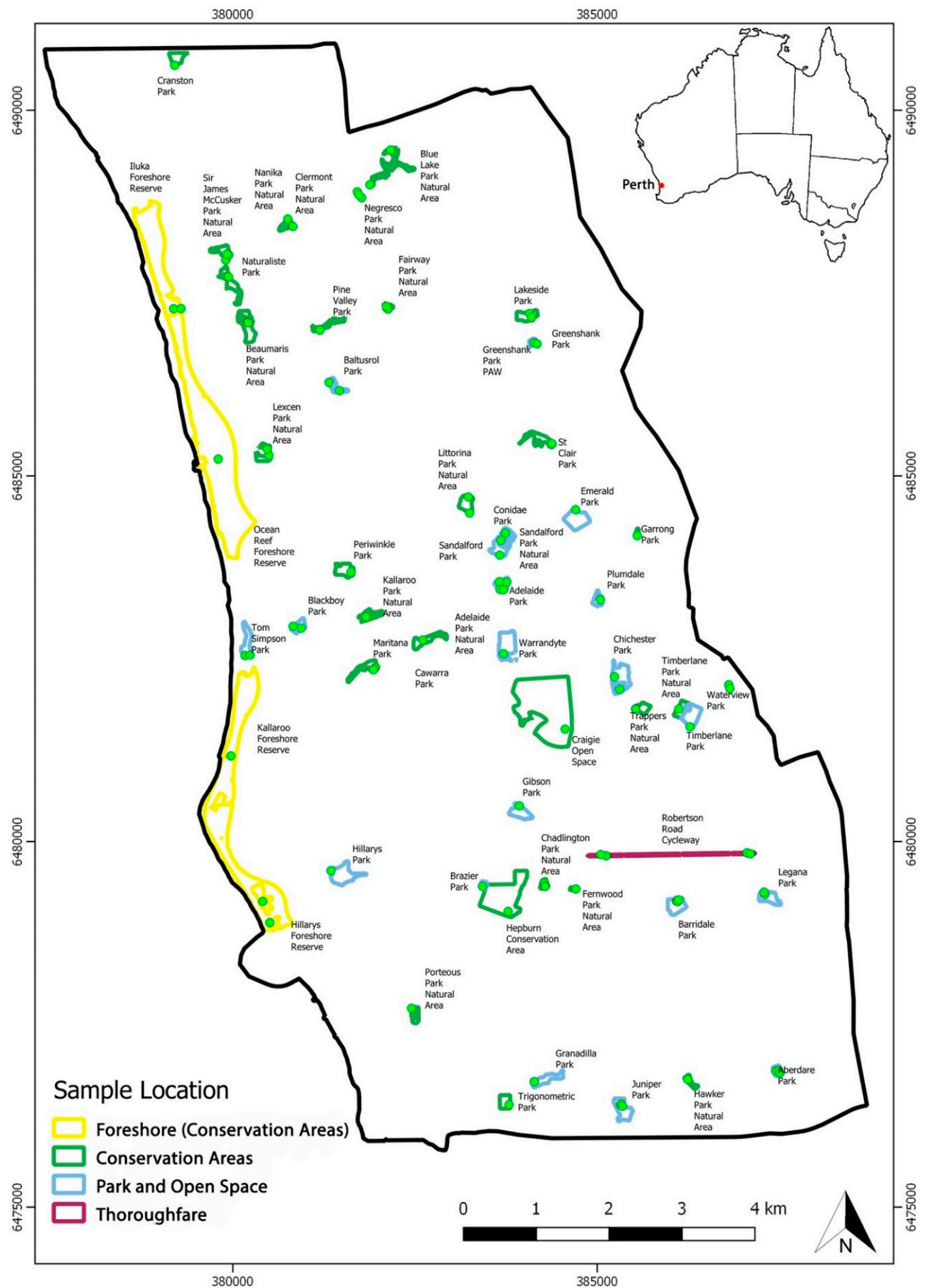

Figure 1. Location of the 91 parks in the City of Joondalup, Western Australia, assessed by remote sensing. Overall, 236 discrete sampling sites (green dots) were selected among these parks in areas where declining vegetation was observed, and soil and roots were sampled for baiting and metabarcoding. A map of Australia is inserted into the top right corner showing the location of Perth.

For this study, the area was delineated by orthorectified multi-spectral imagery. Between 2012 and 2015, high-resolution digital multi-spectral imagery (DMSI) was captured annually with a fixed-wing aircraft across all urban bushlands in Joondalup, as four narrow spectral bands of data (red, green, 
blue, and near infrared) at a spatial resolution of $0.5 \mathrm{~m}$ pixels. The Red Edge Extrema Index (REEI) was calculated using the ratio of near infrared: red bands, and a difference in pixel values from 2015 to 2012 was calculated by subtracting the 2015 image from the 2012 image [27,28]. An increase in pixel values represent an increase in vegetation condition over this period, while a decrease in pixel values indicates a decline in health. A vegetation feature height model (VFHM) was created by subtracting the digital surface model from the digital terrain model, and a canopy layer was produced by classifying all pixels above $3 \mathrm{~m}$ in height within the VFHM.

Field validation was undertaken at 236 sampling sites within 91 parks where soil and root samples were collected to confirm the presence of Phytophthora species (Figure 1). These samples were collected during summer and autumn from 2014 to 2016, inclusive. At each of the sampling sites a bulked sample was collected by combining several smaller samples (approximately $150 \mathrm{~g}$ ) of rhizosphere soil collected within $5 \mathrm{~m}$ of the trunks of declining trees. The samples were kept in insulated boxes and transported to the laboratory within $8 \mathrm{~h}$, where they were stored at room temperature $\left(20-22^{\circ} \mathrm{C}\right)$ until processing. Sampling targeted five families known to have genera susceptible to Phytophthora (Proteaceae, Myrtaceae, Fabaceae, Casuarinaceae and Asphodelaceae). Samples were collected from an extensive variety of declining native trees and shrubs predominately species of Acacia, Allocasuarina, Banksia, Corymbia, Eucalyptus, Grevillea, Hibbertia and Xanthorrhoea.

\subsection{Baiting Technique}

For each bulked soil sample (236 in total), $300 \mathrm{~g}$ soil with fine root samples were placed in $1 \mathrm{~L}$ containers $(11.5 \times 16.5 \times 7.5 \mathrm{~mm}$; GENFAC 111 Plastics P/L). The samples were flooded with distilled water (ratio 3:1 water: soil and roots). Floating baits consisted of young leaves from six plant species (Quercus ilex, Q. suber, Pimelea ferruginea, Poplar sp., Scholtzia involucrata and Hedera helix) and containers were incubated at $20-25{ }^{\circ} \mathrm{C}$ for 7 days. Leaves were monitored daily and those baits with lesions were removed, dried on paper towels and $2-\mathrm{mm}^{2}$ lesioned sections were placed on NARH, a Phytophthora selective agar medium [29]. Plates were incubated in the dark at room temperature and examined daily for colonies typical of Phytophthora species. Any Phytophthora growth was sub-cultured onto fresh NARH plates and ultimately transferred onto vegetable juice agar (V8A) plates; $100 \mathrm{~mL}$ filtered vegetable juice (Campbells V8 vegetable juice; Campbell Grocery Products Ltd., Norfolk, UK), 900 mL distilled water, $0.1 \mathrm{~g} \mathrm{CaCO}_{3}$, and $17 \mathrm{~g}$ Laboratory-grade agar (Becton, Dickenson and Company, Sparks, MD, USA), adjusted to $\mathrm{pH} 7$. The soil was then allowed to dry for 7 days and baited a second time to increase the chance of isolation success [30].

\section{3. eDNA Extraction from Fine Roots and Metabarcoding}

Prior to baiting, a sub-sample was taken, air-dried, and 60-80 g was ground to a fine powder using the TissueLyser LT (Qiagen, Hilden, Germany). Between each sample, the grinding tubes were cleaned by detergent (Pyroneg), rinsed in $0.4 \mathrm{mM} \mathrm{HCl}$ for $5 \mathrm{~min}$, rinsed with water, then sprayed with ethanol $70 \%$ and allowed to air dry. Controls were ground with water and all samples were stored at $-20^{\circ} \mathrm{C}$. DNA extractions were performed using the Mo-Bio PowerSoil DNA isolation kit (Carlsbad, CA, USA) following the manufacturer's protocol. Three independent runs were conducted. Amplicon pyrosequencing and clustering were conducted as described previously [16,17]. Briefly, sequences that passed quality checks were imported into Geneious vR9 and sorted into separate files based on their unique barcode. Clustering was performed for each barcode and then the consensus sequences (from both runs were combined and aligned using MAFFT within the Geneious program. Identities were assigned to consensus sequences by conducting an internal blast search firstly against a customized reference database (available upon request from the authors at Phytophthora Science and Management, Murdoch University) and secondly against GenBank. Consensus sequences were then sorted into clades (Figure S1, https://idtools.org/id/phytophthora/molecular.php,) and phylogenetic analyses were conducted for each clade using Geneious tree builder. These final identities were considered phylotypes and represent a new species if they did not match any known species in the 
phylogenetic analysis. Each Phytophthora species was classified as either native or introduced based on patterns of diversity and distribution of representative clades, prior literature, and in some cases comparisons of genetic diversity [17]. Since origin, particularly for microbes, can be difficult to discern and is subject to historical sampling and geographic biases, our designations should be considered as working hypotheses; we have thus used the term 'putative' to classify these species.

\subsection{Data Analysis}

Two categorical (park class, soil family) and three continuous variables (park area, canopy cover and canopy health) were examined (Table 1, Table S1). The Phytophthora community was down-sampled to the same number of reads (1000 reads per sample) using the rarefy function in the Vegan package of $R$ [31]. Statistical analyses were performed on the presence/absence data to determine if there was a correlation between the five variables and the Phytophthora community at the sites using the Adonis function in the Vegan package for R [31]. Jaccard and Bray-Curtis dissimilarity matrices were created and utilized for presence and abundance analyses, respectively. Only sites $(n=168)$ where Phytophthora was recovered were used in the analysis. Each dissimilarity matrix had a permutational multivariate analysis of variance (PERMANOVA) performed with 9999 permutations. The environmental variables (categorical) fit the assumption of homogeneity of multivariate dispersions. The Bray-Curtis Phytophthora communities were displayed using unconstrained ordination and non-metric multidimensional scaling (NMDS). Ellipses encompassed 95\% of the variation in categorical variables. Continuous variables were displayed on NMDS plots using the envfit function. Species co-occurrence was assessed using the cooccur function with a threshold of $>1$ in the cooccur R package [32]. Sites with the dominant invasive Phytophthora species, P. cinnamomi and P. multivora were visualized using a Venn diagram constructed in $\mathrm{R}$ with the VennDiagram package.

Table 1. Data sources and spatial scales for each of the variables examined for sampling sites from which Phytophthora was recovered $(n=168)$. The number of sample sites in each category are in brackets.

\begin{tabular}{|c|c|c|}
\hline Factor & Source & Description \\
\hline Park Class & City of Joondalup & $\begin{array}{c}\text { GIS layer units; open space-mainly sport parks (25), } \\
\text { conservation areas (117), parks (32) and thoroughfares (4). } \\
\text { See Figure } 1 .\end{array}$ \\
\hline Soil Family & $\begin{array}{l}\text { Department of Primary Industries } \\
\text { and Regional Development }\end{array}$ & $\begin{array}{c}\text { DAFWA-033 Soil Landscape Mapping WA-best available; } \\
\text { LS1 and S7 (24), Quindalup (46), Karrakatta (88) and } \\
\text { Spearwood (10) soils. }\end{array}$ \\
\hline Park Area & City of Joondalup & $\begin{array}{l}\text { Internal GIS layers. Area calculated from polygon layers. } \\
\text { Ranged in area from } 0.5 \text { to } 108 \text { ha. Large park area was deemed } \\
\text { to be those sites with area }>0.5 \text { SD above the mean, medium } \\
\leq 0.5 \text { SD from the mean, and small at }>0.5 \text { SD below the mean. } \\
\text { Standard deviation (SD) of plant cell density (PCD }=\text { IR/Red) }\end{array}$ \\
\hline Canopy cover & digital multispectral imagery & $\begin{array}{l}\text { from pixels within } 5 \mathrm{~m} \text { of the sample point, ranged from } 0.005 \\
\text { to } 170 \text { ha. High canopy cover was deemed to be those sites } \\
\text { with canopy cover }>0.5 \mathrm{SD} \text { above the mean, medium } \leq 0.5 \mathrm{SD} \\
\text { from the mean, and small at }>0.5 \mathrm{SD} \text { below the mean. }\end{array}$ \\
\hline Canopy health & digital multispectral imagery & $\begin{array}{c}\text { SD of Red Edge Extrema Index (REEI = NIR/Red) from pixels } \\
\text { of the sample point. The images were acquired in } 2012 \text { and } \\
2015 \text {, ranging from }-17.4 \text { to }+19.5 \text {. A -ve value represents a } \\
\text { decrease in canopy health. }\end{array}$ \\
\hline
\end{tabular}

\section{Results}

\subsection{Isolation and Identification}

Only four species of Phytophthora (P. nicotianae, P. multivora, P. boodjera and P. arenaria) were isolated by baiting from 24 sampling sites (10\%) from 18 parks (20\%) (Table 2). This result was substantially less than the 44 Phytophthora phylotypes detected by metabarcoding (Table 2, Figure S1, Table S2). The metabarcoding runs yielded a total of 193747 reads from 168 samples (71\%) in 69 parks (76\%) with an average of $1153 \pm 57$ reads per site (range: 62-5922). For the sampling sites where Phytophthora was 
detected, there was a mean species richness of 5.8 (in the range from one to 21). Phytophthora multivora was the most widely distributed species, detected at 52 parks and 130 samples, followed by P. arenaria from 98 samples, P. amnicola from 88 samples, P. cinnamomi from 81 samples, P. pseudocryptogea from 77 samples and P. nicotianae from 70 samples (Table 2, Figure 2a). Of the 44 phylotypes, six (P. capsici, P. sp. pecan, $P$. fluvialis, $P$. gonapodyides, $P$. sp. walnut and P. fallax) were rare, accounting for less than 100 of reads and only detected from a single sample (Table 2).

Table 2. Phytophthora species $(n=44)$ detected by metabarcoding from the urban forest in the City of Joondalup, Western Australia.

\begin{tabular}{|c|c|c|c|c|c|c|c|c|}
\hline Phytophthora Species & Clade & $\begin{array}{l}\text { No. of } \\
\text { Parks }\end{array}$ & $\begin{array}{l}\text { No. of } \\
\text { Samples }\end{array}$ & Reads & $\begin{array}{l}\text { Rarefied } \\
\text { Read No. }\end{array}$ & Baiting 1 & $\begin{array}{c}\text { First } \\
\text { Record }^{2}\end{array}$ & Status $^{3}$ \\
\hline P. cactorum & 1 & 2 & 2 & 165 & 13 & & 2014 & I \\
\hline P. nicotianae & 1 & 42 & 70 & 8262 & 550 & $5(4)$ & 2004 & I \\
\hline P. AUS1D ${ }^{4}$ & 1 & 7 & 9 & 7667 & 287 & & & $\mathrm{~N}$ \\
\hline P. AUS2A 4,5 & 2 & 11 & 12 & 620 & 33 & & & I \\
\hline P. AUS2B 4,5 & 2 & 16 & 22 & 8912 & 303 & & & I \\
\hline P. capensis 4 & 2 & 14 & 25 & 6359 & 251 & & & I \\
\hline P. capsici $^{4}$ & 2 & 1 & 1 & 92 & 12 & & & I \\
\hline P. citrophthora & 2 & 18 & 28 & 3113 & 169 & & 2015 & I \\
\hline P. elongata & 2 & 6 & 6 & 105 & 2 & & & $\mathrm{~N}$ \\
\hline P. frigida 4 & 2 & 4 & 4 & 43 & 10 & & & I \\
\hline P. multivora & 2 & 52 & 130 & 63,649 & 3251 & $15(11)$ & 1985 & I \\
\hline P. pachypleura ${ }^{4}$ & 2 & 13 & 15 & 2268 & 83 & & & I \\
\hline P. arenaria & 4 & 54 & 98 & 13,221 & 783 & $3(2)$ & & $\mathrm{N}$ \\
\hline P. boodjera & 4 & 19 & 23 & 4049 & 263 & $1(1)$ & 2011 & $\mathrm{~N}$ \\
\hline P. palmivora & 4 & 14 & 16 & 461 & 41 & & 2011 & I \\
\hline P. sp. pecan 4,5 & 4 & 1 & 1 & 2 & 0 & & & I \\
\hline P. amnicola & 6 & 46 & 88 & 12,384 & 750 & & & $\mathrm{~N}$ \\
\hline P. bilorbang & 6 & 11 & 14 & 962 & 81 & & & $\mathrm{~N}$ \\
\hline P. crassamura & 6 & 11 & 15 & 6225 & 224 & & & I \\
\hline P. fluvialis & 6 & 1 & 1 & 68 & 5 & & & $\mathrm{~N}$ \\
\hline P. gonapodyides 4,5 & 6 & 1 & 1 & 9 & 1 & & & I \\
\hline P. gregata & 6 & 11 & 14 & 300 & 31 & & 2015 & $\mathrm{~N}$ \\
\hline P. inundata & 6 & 12 & 18 & 405 & 30 & & 2011 & I \\
\hline P. kwongonina & 6 & 25 & 35 & 4006 & 188 & & 2010 & $\mathrm{~N}$ \\
\hline P. lacustris & 6 & 2 & 2 & 19 & 3 & & 1995 & I \\
\hline P. litoralis & 6 & 6 & 10 & 852 & 35 & & 2011 & $\mathrm{~N}$ \\
\hline P. moyootj & 6 & 11 & 15 & 2602 & 132 & & & $\mathrm{~N}$ \\
\hline P. rosacearum & 6 & 9 & 13 & 1332 & 67 & & 2015 & $\mathrm{~N} ?$ \\
\hline P. sp. walnut 4,5 & 6 & 1 & 1 & 32 & 2 & & & $\mathrm{~N} ?$ \\
\hline P. thermophila & 6 & 39 & 69 & 6667 & 432 & & 1995 & $\mathrm{~N}$ \\
\hline P. cambivora & 7 & 5 & 5 & 1329 & 67 & & & I \\
\hline P. cinnamomi & 7 & 40 & 81 & 11,623 & 707 & & $\propto 1980$ & I \\
\hline P. fragariae 4,5 & 7 & 6 & 8 & 342 & 14 & & & I \\
\hline P. niederhauserii & 7 & 2 & 2 & 276 & 20 & & 2012 & I \\
\hline P. cryptogea & 8 & 3 & 3 & 189 & 12 & & 2015 & I \\
\hline P. drechsleri 4 & 8 & 2 & 2 & 27 & 0 & & & I \\
\hline P. erythroseptica & 8 & 2 & 2 & 19 & 2 & & & I \\
\hline P. pseudocryptogea & 8 & 39 & 77 & 14,329 & 924 & & 2016 & I \\
\hline P. sp. kelmania & 8 & 5 & 7 & 1832 & 232 & & 2016 & I \\
\hline P. AUS8C 4,5 & 8 & 1 & 2 & 162 & 10 & & & $\mathrm{~N} ?$ \\
\hline P. constricta & 9 & 7 & 11 & 500 & 20 & & & $\mathrm{~N}$ \\
\hline P. fallax ${ }^{4}$ & 9 & 1 & 1 & 26 & 3 & & & $\mathrm{~N} ?$ \\
\hline P. versiformis & 11 & 15 & 16 & 6119 & 298 & & 2011 & $\mathrm{~N}$ \\
\hline P. AUS11A 4 & 11 & 3 & 3 & 2126 & 65 & & & $\mathrm{~N}$ \\
\hline Total & & & & 193,747 & 10,416 & $24(18)$ & & \\
\hline
\end{tabular}

${ }^{1}$ Number of isolates recovered through baiting (number of sites in brackets). ${ }^{2}$ First recorded in Perth urban forest. ${ }^{3}$ Status: I = introduced, $\mathrm{N}=$ native or $\mathrm{N}$ ? = putatively native. ${ }^{4}$ Never isolated in Western Australia (WA). ${ }^{5}$ First detection in WA by metabarcoding.

Thirty-six phylotypes were matched with described species. In addition, there were three phylotypes that were matched with 'designated' but undescribed species ( $P$. sp. pecan, $P$. sp. walnut and $P$. sp. kelmania) and five phylotypes were identified as potential new taxa (P. AUS1D, P. AUS2B, P. AUS2B, P. AUS8C and P. AUS11A) (Table 2). Fifteen of the species detected (P. AUS2B, P. AUS2A, P. sp. pecan, P. gonapodyides, P. sp. walnut, P. fragariae, P. AUS8C, P. drechsleri, P. capensis, P. pachypleura, P. frigida, P. AUS1D, P. capsici, P. fallax, P. AUS11A) have never been isolated in WA (and confirmed by molecular 
diagnostics), of which the first seven have not been detected in previous metabarcoding studies (Table 2). For 19 of the described species, the first isolates found in WA were from the urban forest (Table 2).

a.

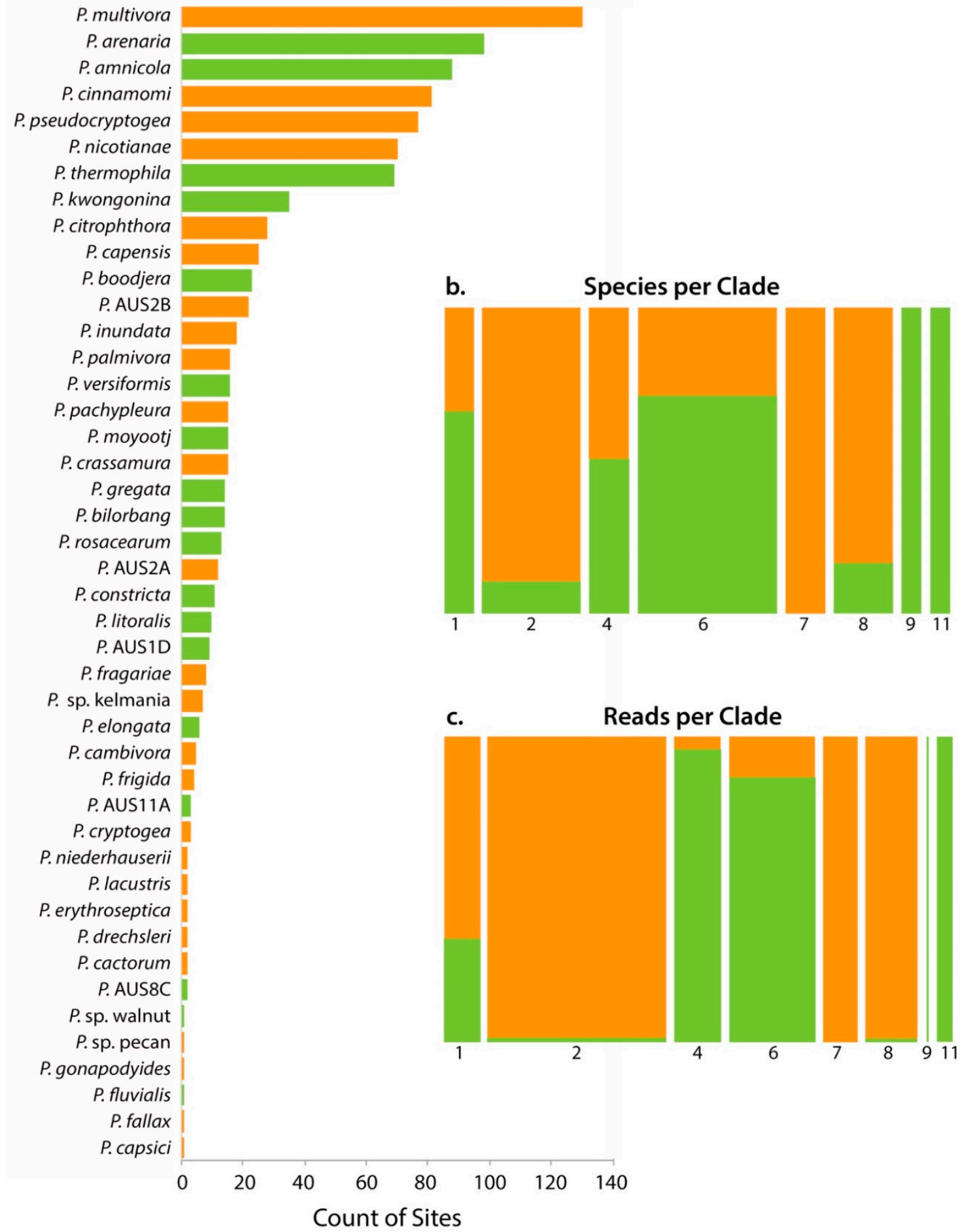

Figure 2. (a) Rank-frequency curve for the 44 Phytophthora species detected in this study by metabarcoding. Orange bars are the putatively introduced taxa while green denotes putatively native status. Mosaic plot showing the distribution of native and introduced Phytophthora species by (b) the number of species per clade-the bar width is proportional to the number of species, (c) rarefied read number per clade - the bar width is proportional to the number of reads. Bar heights $(\mathbf{b}, \mathbf{c})$ show the relative proportion of native: introduced Phytophthora phylotypes per clade. 
Fifty-five percent of the species found were putatively designated as introduced, while the remainder were designated as putatively native (Table 2, Figure 2). There was unequal phylotype distribution across the Phytophthora clades; one third belonged to clade 6, while only two phylotypes were identified from clades 9 and 11 (Table 2, Figure 2b). Species in clades 6, 9 and 11 were predominately considered native, while most of those in clades 2, 7 and 8 were considered introduced (Table 2, Figure $2 b$ ). While there were more species detected from clade 6 , most of the reads were from clade 2 (Table 2, Figure $2 \mathrm{~b}, \mathrm{c}$ ). Two species were detected from clade 9 , but they accounted for very few reads (Table 2, Figure $2 b, c$ ).

\subsection{Phytophthora Community}

The PERMANOVA analysis of potential relationships of the Phytophthora community using presence/absence data revealed a significant $(p<0.05)$ relationship but a small impact $\left(R^{2}<0.03\right)$ for canopy cover and park area (Table 3, Figure 3a). NMDS plots illustrate the complete overlap of Phytophthora communities (ellipses overlap) observed for park class and soil family (Figure 3b-c). The other variables show a similar pattern. Twenty-eight of the Phytophthora species detected had associations with at least one other species, while 18 species had no associations and were dropped from the matrix (Figure 4a). Species co-occurrence found 89 species pairs had a positive correlation, and three had a negative association (Figure $4 \mathrm{a}$, Table S3).

Table 3. PERMANOVA analysis showing correlation between five variables and the Phytophthora community based both on presence/absence data and number of reads. Bold $P$ values indicate a significant relationship. Low $\mathrm{R}^{2}$ values indicate that while significant these variables had little effect on the Phytophthora community.

\begin{tabular}{cccccccccccc}
\hline & \multicolumn{9}{c}{ Presence } \\
\hline Factor & df & SS & MS & F-Value & $\mathbf{R}^{\mathbf{2}}$ & $\boldsymbol{P}$-Value & SS & MS & F-Value & $\mathbf{R}^{\mathbf{2}}$ & $\boldsymbol{P}$-Value \\
\hline Global & & & & & & & & & & \\
Park Area & 1 & 1.64 & 1.64 & 5.51 & 0.03 & $\mathbf{0 . 0 0 0 1}$ & 1.52 & 1.52 & 4.71 & 0.03 & $\mathbf{0 . 0 0 0 1}$ \\
Park Class & 3 & 1.06 & 0.35 & 1.19 & 0.02 & 0.1809 & 0.94 & 0.31 & 0.97 & 0.02 & 0.5009 \\
Canopy Cover & 1 & 0.90 & 0.90 & 3.01 & 0.02 & $\mathbf{0 . 0 0 0 1}$ & 1.51 & 1.51 & 4.68 & 0.03 & $\mathbf{0 . 0 0 0 1}$ \\
Canopy Health & 1 & 0.35 & 0.35 & 1.16 & 0.01 & 0.2890 & 0.40 & 0.40 & 1.25 & 0.01 & 0.2256 \\
Soil Family & 3 & 1.33 & 0.44 & 1.48 & 0.03 & $\mathbf{0 . 0 2 0 4}$ & 1.35 & 0.45 & 1.39 & 0.02 & 0.0532 \\
Residuals & 158 & 47.04 & 0.30 & & 0.89 & & 51.08 & & & 0.89 & \\
Total & 167 & 52.31 & & & 1.00 & & 56.81 & & & 1.00 & \\
\hline
\end{tabular}
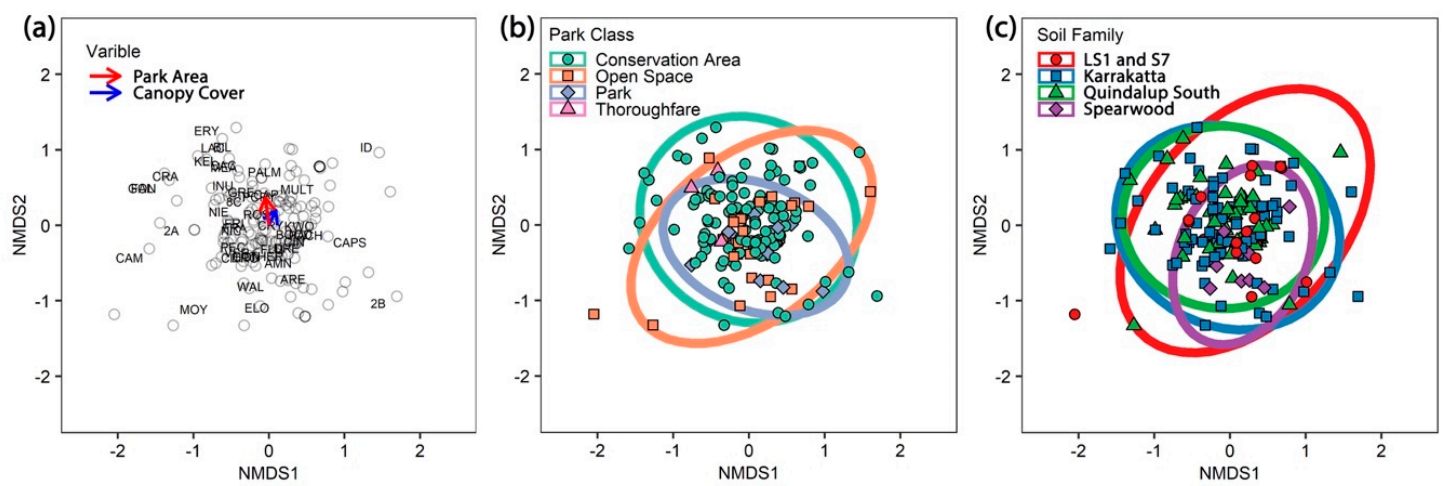

Figure 3. (a) Non-metric multidimensional scaling (NMDS) plot showing the significant continuous variables park area and canopy cover. Phytophthora species codes and site (hollow points) are displayed on the plot. The arrow length is proportional to the degree of correlations between the variable and the ordination. The arrows are very short indicating minimal correlation. $(\mathbf{b}, \mathbf{c})$ NMDS plots of Phytophthora communities showing the complete overlap of ellipses for (b) park class, and (c) soil family. 
(a)

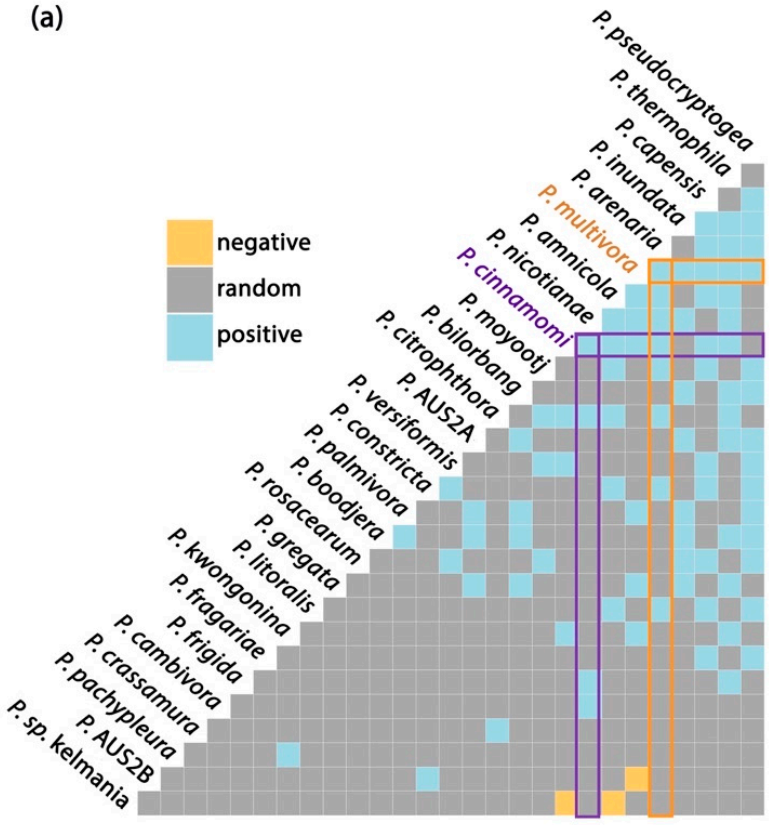

(b)

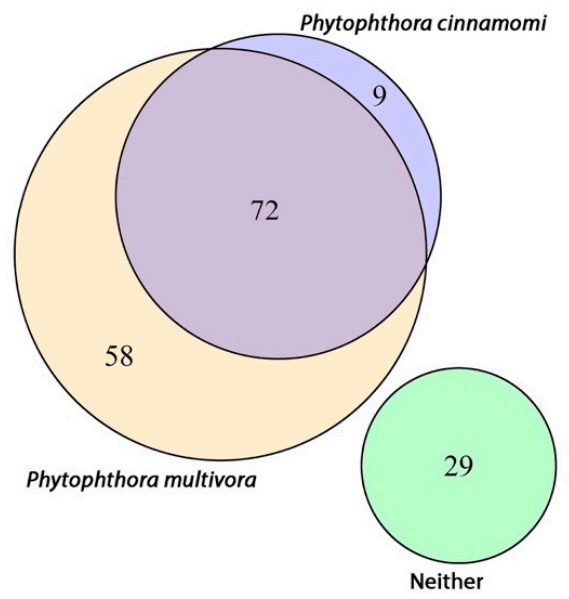

Figure 4. (a) Pairwise co-occurrence matrix for a subset of Phytophthora species that exceeded a minimum threshold of expected co-occurrence ( $>1$ site). Orange and blue tiles correspond to species pairs that were less or more likey to co-occur than predicted by a null model. (b) Venn diagram of detections from 168 sampling sites showing the relationship between the two main invasive species,

Phytophthora cinnamomi and P. multivora.

\subsection{Distribution of Phytophthora cinnamomi and P. multivora}

Phytophthora cinnamomi and P. multivora are the dominant invasive species with known impact in Perth, Western Australia. Across the 168 sites, P. multivora was detected from $77 \%$ of sites and P. cinnamomi from $48 \%$ of sites. Phytophthora cinnamomi was mostly detected at sites also containing P. multivora, while P. multivora was often detected alone (Figure 4b). Phytophthora multivora and P. cinnamomi were more likely than chance to occur with one another (Figure 4a), and the two species had the third highest probability of occurrence (37.3\%) of all species pairs. Both species were likely to co-occur with the other commonly detected species $P$. arenaria, $P$. capensis, $P$. thermophila, $P$. nicotianae and P. citrophthora, while P. multivora was also likely to co-occur with P. pseudocryptogea, P. inundata, $P$. constricta and P. litoralis and P. cinnamomi was more likely to co-occur with P. cambivora and P. frigida (Figure 4a).

\section{Discussion}

Urban parks, whether conservation areas and those that are mostly turf, harbor an unexpected diversity of Phytophthora. A decrease in canopy cover and an increase in park area proved to be a weak predictor of the Phytophthora community in the urban parks, while canopy health and park class had no influence. Soil baiting recovered only four species, from $10 \%$ of sampling sites and $20 \%$ of the parks, while metabarcoding of the same samples detected 44 species from $71 \%$ of sampling sites and $76 \%$ of the parks. These results are comparable to previous studies where both isolations and metabarcoding have been conducted (see Khaliq, Hardy, White and Burgess [16] for a detailed summary). Twenty-five species (including four putative new species and three informally named species) were detected for the first time associated with the urban landscape of Perth, WA.

\subsection{Bridgehead Effect}

Globalization has increased the frequency of inadvertent introductions of plant pathogens [33], and urban environments provide the opportunity for early detections of these pathogens, as has 
been demonstrated for Phytophthora [13]. Urban forests contain relatively high levels of diversity, and often a mix of native and exotic tree species which provide a range of potential niches for pests and pathogens [4]. In this way, the urban environment functions as a 'bridgehead' [34], as points of entry for new pests and pathogens, providing a suitable environment for them to establish and adapt before moving into native ecosystems [7]. In the unified framework for biological invasions, the urban forests play a dual role as both a point of introduction and as an environment which could facilitate establishment [35].

Many of the Phytophthora species identified in this metabarcoding study were new records for WA. These novel detections were expected, as new species have been detected in all surveys that have used metabarcoding for the detection of Phytophthora [14,17-19,36]. However, the south-west of WA has had intensive sampling for Phytophthora undertaken both in native vegetation, urban parks and gardens for over 40 years [37]. This region has been well explored and in the last decade 20 new Phytophthora species have been described [38-49]. Hence, unlike many other regions, the baseline of Phytophthora species in the south-west of WA is well established. Thus, the detection of 25 species $(55 \%$ of all species) for the first time in association with the urban environment was unexpected. Of these 15 have never been isolated in WA, which points to the urban environment being a reservoir of potential invasive pathogens.

\subsection{Phytophthora Species Detected}

Before this study, P. cinnamomi and 18 of the other species had previously been isolated from the urban forest of WA. Of these, most were first isolated in the last decade (Barber et al., 2013; Scott et al., 2013). For example, P. citrophthora (28 sampling sites) was first recorded in agriculture in 1923 [50] and in the urban forest in 2015 (CPSM diagnostics). This citrus pathogen has been associated with nursery plants imported into WA [50]. Phytophthora cactorum (two samples) is pathogenic to more than 200 plant species within different plant families [51] and was recorded in agriculture in 2006, and in the urban forest in 2014 (CPSM diagnostics). Phytophthora litoralis (10 samples) was recorded in natural ecosystems in 2006 and in the urban forest in 2011 [41], while P. boodjera (24 samples) was first isolated from a native environment in 2016, from the urban environment in 2011 and from a native plant nursery in 2012 [47]. Some Phytophthora species have been recorded in agriculture, the urban forest and the natural ecosystem. More prolific, P. thermophila (69 samples) appears to be native to WA [41], and has been recorded in water ways, the urban forest, agriculture and natural ecosystems [41,52,53]. These observations together illustrate the potential for species to move between environments.

Of the 25 species not previously isolated from the urban environment of Perth, ten have been isolated previously from other WA environments (native ecosystems, forestry, agriculture). Consequently, their detection within parks and conservation reserves within the urban environment was not unexpected. Two pathogens commonly found in agriculture were detected; P. erythroseptica, a potato pathogen [51], from two samples, and P. fragariae, a strawberry pathogen [54], from eight samples. This spread of agricultural crop pathogens into the urban forest, and also the detection of species strongly associated with native ecosystems, provides evidence of movement through human activity most likely in the nursery trade or via soil attached to machinery or equipment. Conversely, several Phytophthora species considered to be native to WA, but not previously isolated from the urban environment were detected. For example, P. arenaria was detected from 98 samples and P. amnicola was detected from 88 samples. These findings suggest that these native species were already present although not previously isolated, perhaps because they are not causing disease symptoms.

Of the 15 species only known in WA from metabarcoding, seven species were detected for the first time in this study. Most of these species are considered to be introduced which supports the role of the urban environment as the pathway by which new Phytophthora species eventually reach natural ecosystems and other environments. There is strong evidence from several studies that the first entry into a new country is by distribution via the global nursery trade $[7,13,55,56]$. The bridgehead effect scenario considers urban environments to be a central source for the spread of Phytophthora 
species into natural ecosystems through many pathways including plant material, aquatic sources, human activities, and equipment. It should be noted that Australia now has very strict quarantine regulations around the movement of plants-for-planting [57], and new detections may be a reflection of an historical rather than a contemporary introduction.

\subsection{Impact of Parks Class and Area, Canopy Cover and Health on Phytophthora Community}

It was assumed that park class would have a significant influence on the Phytophthora community as recreational parks have a high rate of human traffic and are mainly comprised of turf, contain many exotic tree species and are watered and fertilized. While conservation areas more closely resemble native forests; they have no cleared areas and receive little management and have less human traffic. It was hypothesized that the managed parks would have more introduced Phytophthora species while the conservation parks would have more native Phytophthora species. However, the observed Phytophthora community was not correlated with any of the measured variables: park class, park area, canopy cover, canopy health or soil type. We suspect that the main reason for the similarity in the Phytophthora community was due to the uniformity of the sampling unit which was trees and shrubs native to the region, never turf. Thus, while the majority of the managed parks may be predominantly turf, the areas sampled contained trees. It is also important to note that before the installation of turf the majority of these areas were occupied by native vegetation, some less than 20 years ago. It was also expected that canopy cover and health, as measured by remote sensing, may be a determinant of Phytophthora disease, with the lower canopy cover and less healthy canopies being indicative of specific Phytophthora communities. However, field validation highlighted that there were other causes for poor tree health, including drought, insect damage and other pathogens [58].

\subsection{Relationship between Commonly Detected Species}

In the current study, the species that were most widely distributed in the urban forests were P. multivora (clade 2), P. arenaria (clade 4), P. amnicola (clade 6), P. cinnamomi (clade 7), P. pseudocryptogea (clade 8) and P. nicotianae (clade 1). All these species are widespread throughout Australia [59]. Phytophthora arenaria was described from WA and has never been found outside Australia [42]. Phytophthora amnicola was also described from WA and is from a cluster of closely related species commonly found in the south-west of WA $[43,60]$. Phytophthora multivora was described from WA, including isolates from Perth [38], but it has subsequently been reported globally, including from asymptomatic native vegetation in South Africa [61]. The description of P. pseudocryptogea included isolates from WA [46]; however it has a comprehensive global distribution in nurseries, orchards and natural forests, and many isolates formerly described as P. cryptogea are likely to be reclassified to P. pseudocryptogea. Phytophthora nicotianae has a global distribution and causes many well-known diseases, especially in nurseries and agriculture [62]. Phytophthora cinnamomi is listed as one of the 100 worst invasive alien species [63] and considered one of the pathogens with the largest global distribution and impact across a range of environments [64]. Phytophthora arenaria and P. amnicola are considered native to Australia, while the rest are considered to be introduced species and are all well-known pathogens. In the co-occurrence matrix, many of the commonly detected species were positively correlated. Interestingly, these species are very similar to the positively co-occurring species in the Australia-wide metabarcoding survey [59].

Of the commonly detected species P. cinnamomi and P. multivora are the most widespread and devastating pathogens in natural ecosystems in WA. Phytophthora cinnamomi has been present in south-western WA from at least the early 1900's and is now widely distributed in the region, including Perth. However, in recent years, P. multivora has been the most commonly isolated species from dead and dying woody plants in the urban environment in Perth [52], and can infect a wide range of native and introduced host plants common in the urban forest of Perth [65]. In the current study, P. multivora dominated the isolations by baiting and there were no recoveries of P. cinnamomi. Similarly, P. multivora was detected more often in the metabarcoding study (130 samples from 52 parks) than P. cinnamomi 
(81 samples in 40 parks) and, overall, there were five times more reads for P. multivora. The study shows that while only P. multivora was isolated, P. cinnamomi was still present, but probably at a lower inoculum load. In the co-occurrence matrix there were other Phytophthora species positively correlated to both P. multivora and P. cinnamomi, but there were some species more likely to occur with only one of them. This could suggest some shaping of the community, but the main driver of this was not determined in the current study. Phytophthora cinnamomi is believed to be a poor saprophyte in soil [66] without long-term survival propagules [67], while P. multivora readily produces thick-walled oospores which can be long-term survival propagules [38]. Phytophthora multivora may displace P. cinnamomi in the future. There was a weak association between soil type and the Phytophthora community, with P. cinnamomi less common on the more calcareous soil types. Phytophthora multivora is known to have a broader $\mathrm{pH}$ tolerance [38], and the other Phytophthora species found in association with it may have the same trait, but this is yet to be tested.

\section{Conclusions}

Paap, Burgess and Wingfield [7] proposed the dual role of the urban forest in pest invasion biology: firstly, as a niche that allows newly introduced species to adapt to the new environment, and secondly (and concurrently) as a monitoring opportunity to perform targeted searches for newly invasive species before they move into natural ecosystems. This study, while not fulfilling the primary objective to find a correlation between the Phytophthora community and tree health, has provided a baseline of Phytophthora species in the urban environment of Perth, which includes many species not previously detected in the region. Future studies will be based around understanding which Phytophthora species become invasive and the pathways by which they move to the natural ecosystem. Similar studies conducted in Sweden have shown that the urban environment was a reservoir of invasive Phytophthora species, where a reduction in species was found as sampling moved to less disturbed sites and then finally into the native forest due to environmental filtering [68]. Future studies will be based around understanding which Phytophthora species become invasive and the pathways by which they move into the natural ecosystem.

Supplementary Materials: The following are available online at http://www.mdpi.com/2076-2607/8/7/973/s1, Figure S1: Bayesian tree based on ITS1 gene region containing representative sequences of all phylotypes found in the current study. For visualisation purposes and for the identification of Molecular Operational taxonomic Units (MOTU), the phylogeny was divided into two separate analyses (a) clades $1-4$, and 11 (b) clades 6-9. MOTUs were assigned to new phylotypes if they did not match any known Phytophthora species. Bayesian posterior probabilities are given above the branch. Table S1: Variables measured for each of the sites sampled. Table S2: Data matrix for all sampling sites from which Phytophthora was detected giving the number of reads for each of the 44 Phytophthora species. Table S3: Co-occurrence species matrix.

Author Contributions: Conceptualization, T.I.B., P.A.B. and G.E.S.H.; methodology, M.Y.K., T.I.B., P.A.B. and G.E.S.H.; validation, C.M., E.J.S. and C.S.; formal analysis, C.M., E.J.S. and C.S.; investigation, M.Y.K.; resources, T.I.B. and G.E.S.H.; data curation, C.M., E.J.S., C.S., P.A.B. and T.I.B.; software, C.M., E.J.S. and C.S.; visualization, C.S. and T.I.B.; writing-original draft preparation, M.Y.K.; writing—review and editing, T.I.B., P.A.B., C.S. and G.E.S.H.; supervision, T.I.B., P.A.B. and G.E.S.H. All authors have read and agreed to the published version of the manuscript.

Funding: This research received no external funding.

Acknowledgments: We thank the Higher Committee for Education Development in Iraq who provided the scholarship for Mohammed Y. Khdiar. Briony Williams assisted with the baiting of the samples. Diane White supervised the sample preparation for metabarcoding. Kay Howard reviewed the manuscript. Naviin Hardy drew Figure 1.

Conflicts of Interest: The authors declare no conflict of interest. 


\section{References}

1. Nowak, D.J.; Noble, M.H.; Sisinni, S.M.; Dwyer, J.F. People and trees: Assessing the US urban forest resource. J. Forestry Res. 2001, 99, 37-42.

2. Konijnendijk, C.C.; Ricard, R.M.; Kenney, A.; Randrup, T.B. Defining urban forestry-A comparative perspective of North America and Europe. Urban For. Urban Gree. 2006, 4, 93-103. [CrossRef]

3. Nowak, D.J.; Walton, J.T. Projected urban growth (2000-2050) and its estimated impact on the US forest resource. J. Forest. 2005, 103, 383-389.

4. Colunga-Garcia, M.; Magarey, R.A.; Haack, R.A.; Gage, S.H.; Qi, J. Enhancing early detection of exotic pests in agricultural and forest ecosystems using an urban-gradient framework. Ecol. Appl. 2010, 20, 303-310. [CrossRef] [PubMed]

5. Simberloff, D. The role of propagule pressure in biological invasions. Ann. Rev. Ecol. Evol. Syst. 2009, 40, 81-102. [CrossRef]

6. Pautasso, M.; Schlegel, M.; Holdenrieder, O. Forest health in a changing world. Microb. Ecol. 2015, 69, 826-842. [CrossRef]

7. Paap, T.; Burgess, T.I.; Wingfield, M.J. Urban trees: Bridge-heads for forest pest invasions and sentinels for early detection. Biol. Invasions 2017, 19, 3515-3526. [CrossRef]

8. Park, J.; Park, B.; Veeraraghavan, N.; Jung, K.; Lee, Y.-H.; Blair, J.E.; Geiser, D.M.; Isard, S.; Mansfield, M.A.; Nikolaeva, E. Phytophthora database: A forensic database supporting the identification and monitoring of Phytophthora. Plant Dis. 2008, 92, 966-972. [CrossRef]

9. Freer-Smith, P.; El-Khatib, A.; Taylor, G. Capture of particulate pollution by trees: A comparison of species typical of semi-arid areas (Ficus nitida and Eucalyptus globulus) with European and North American species. Water Air Soil Poll. 2004, 155, 173-187. [CrossRef]

10. Tubby, K.; Webber, J. Pests and diseases threatening urban trees under a changing climate. Forestry 2010, 83, 451-459. [CrossRef]

11. Niinemets, Ü.; Valladares, F. Tolerance to shade, drought, and waterlogging of temperate Northern Hemisphere trees and shrubs. Ecol. Monog. 2006, 76, 521-547. [CrossRef]

12. Lloret, F.; Keeling, E.G.; Sala, A. Components of tree resilience: Effects of successive low-growth episodes in old ponderosa pine forests. Oikos 2011, 120, 1909-1920. [CrossRef]

13. Hulbert, J.M.; Agne, M.C.; Burgess, T.I.; Roets, F.; Wingfield, M.J. Urban environments provide opportunities for early detections of Phytophthora invasions. Biol. Invasions 2017, 19, 3629-3644. [CrossRef]

14. Riddell, C.E.; Frederickson-Matika, D.; Armstrong, A.C.; Elliot, M.; Forster, J.; Hedley, P.E.; Morris, J.; Thorpe, P.; Cooke, D.E.L.; Pritchard, L.; et al. Metabarcoding reveals a high diversity of woody host-associated Phytophthora spp. in soils at public gardens and amenity woodlands in Britain. PeerJ 2019, 7, e6931. [CrossRef]

15. Yang, X.; Tyler, B.M.; Hong, C. An expanded phylogeny for the genus Phytophthora. IMA Fungus 2017, 8, 355-384. [CrossRef]

16. Khaliq, I.; Hardy, G.E.S.J.; White, D.; Burgess, T.I. eDNA from roots: A robust tool for determining Phytophthora communities in natural ecosystems. FEMS Microb. Ecol. 2018, 94, fiy048. [CrossRef]

17. Burgess, T.I.; White, D.; McDougall, K.L.; Garnas, J.; Dunstan, W.A.; Català, S.; Carnegie, A.J.; Worboys, S.; Cahill, D.; Vettraino, A.-M.; et al. Distribution and diversity of Phytophthora across Australia. Pacific Conserv. Biol. 2017, 23, 150-162. [CrossRef]

18. Català, S.; Pérez-Sierra, A.; Abad-Campos, P. The use of genus-specific amplicon pyrosequencing to assess Phytophthora species diversity using eDNA from soil and water in northern Spain. PLoS ONE 2015, 10, e0119311.

19. Bose, T.; Wingfield, M.J.; Roux, J.; Vivas, M.; Burgess, T.I. Community composition and distribution of Phytophthora species across adjacent native and non-native forests of South Africa. Fungal Ecol. 2018, 36, 17-25. [CrossRef]

20. Hopper, S.D.; Gioia, P. The southwest Australian floristic region: Evolution and conservation of a global hot spot of biodiversity. Ann. Rev. Ecol. Evol. Syst. 2004, 35, 623-650. [CrossRef]

21. Nguyen, T.T.; Barber, P.A.; Harper, R.; Linh, T.V.K.; Dell, B. Vegetation trends associated with urban development: The role of golf courses. PLoS ONE 2020, 15, e0228090. [CrossRef]

22. Gillis, T. Use of Remotely Sensed Imagery to Map Sudden Oak Death (Phytophthora ramorum) in the Santa Cruz Mountains. Master's Thesis, University of Southern California, Los Angeles, CA, USA, 2014; p. 125. 
23. Cardillo, E.; Acedo, A.; Abad, E. Topographic effects on dispersal patterns of Phytophthora cinnamomi at a stand scale in a Spanish heathland. PLoS ONE 2018, 13, e0195060. [CrossRef] [PubMed]

24. Hill, R.; Wilson, B.; Rookes, J.; Cahill, D. Use of high resolution digital multi-spectral imagery to assess the distribution of disease caused by Phytophthora cinnamomi on heathland at Anglesea, Victoria. Australas. Plant Pathol. 2009, 38, 110-119. [CrossRef]

25. Rowe, D.; Tille, P.; Kuswardiyanto, K. Land Capability Assessment for Expanding Irrigated Horticulture around Myalup; Department of Primary Industries and Regional Development: Perth, Australia, 2017. Available online: https://researchlibrary.agric.wa.gov.au/rmtr/389/ (accessed on 28 June 2020).

26. Bessell-Browne, J. Kings Park Soil Survey; Department of Agriculture and Food: Kensington, Australia, 1990. Available online: https://researchlibrary.agric.wa.gov.au/rmtr/93/ (accessed on 28 June 2020).

27. Evans, B.; Lyons, T.J.; Barber, P.A.; Stone, C.; Hardy, G.E.S.J. Dieback classification modelling using high resolution digital multi spectral imagery and in situ assessments of crown condition. Remote Sens. Lett. 2012, 3, 541-550. [CrossRef]

28. Evans, B.; Lyons, T.J.; Barber, P.A.; Stone, C.; Hardy, G.E.S.J. Enhancing a eucalypt crown condition indicator driven by high spatial and spectral resolution remote sensing imagery. J. Appl. Remote Sens. 2012, 6, 063605. [CrossRef]

29. Simamora, A.; Paap, T.; Howard, K.; Stukely, M.J.C.; Hardy, G.E.S.; Burgess, T.I. Phytophthora contamination in a nursery and its potential dispersal into the natural environment. Plant Dis. 2018, 102, 132-139. [CrossRef]

30. Jeffers, S.; Aldwinckle, H. Enhancing detection of Phytophthora catorum in naturally infested soil. Phytopathology 1987, 77, 1475-1482. [CrossRef]

31. Community Ecology Package. Version 2.5-6. Available online: https://rdrr.io/cran/vegan/ (accessed on 28 June 2020).

32. Griffith, D.M.; Veech, J.A.; Marsh, C.J. cooccur: Probabilistic species co-occurrence analysis in R. J. Stat. Softw. 2016, 69, 1-17. [CrossRef]

33. Brasier, C.M. The biosecurity threat to the UK and global environment from international trade in plants. Plant Pathol. 2008, 57, 792-808. [CrossRef]

34. Lombaert, E.; Guillemaud, T.; Cornuet, J.-M.; Malausa, T.; Facon, B.; Estoup, A. Bridgehead effect in the worldwide invasion of the biocontrol harlequin ladybird. PLoS ONE 2010, 5, e9743. [CrossRef]

35. Blackburn, T.M.; Pyšek, P.; Bacher, S.; Carlton, J.T.; Duncan, R.P.; Jarošík, V.; Wilson, J.R.; Richardson, D.M. A proposed unified framework for biological invasions. Trends Ecol. Evol. 2011, 26, 333-339. [CrossRef] [PubMed]

36. Prigigallo, M.I.; Mosca, S.; Cacciola, S.O.; Cooke, D.E.L.; Schena, L. Molecular analysis of Phytophthora diversity in nursery-grown ornamental and fruit plants. Plant Pathol. 2015, 64, 1308-1319. [CrossRef]

37. Burgess, T.I.; Webster, J.L.; Ciampini, J.A.; White, D.; Hardy, G.E.S.; Stukely, M.J.C. Re-evaluation of Phytophthora species isolated during 30 years of vegetation health surveys in Western Australia using molecular techniques. Plant Dis. 2009, 93, 215-223. [CrossRef] [PubMed]

38. Scott, P.M.; Burgess, T.I.; Barber, P.A.; Shearer, B.L.; Stukely, M.J.C.; Hardy, G.E.S.; Jung, T. Phytophthora multivora sp. nov., a new species recovered from declining Eucalyptus, Banksia, Agonis and other plant species in Western Australia. Persoonia 2009, 22, 1-13. [CrossRef]

39. Rea, A.; Jung, T.; Burgess, T.I.; Stukely, M.J.C.; Hardy, G.E.S. Phytophthora elongata sp. nov. a novel pathogen from the Eucalyptus marginata forest of Western Australia. Australas. Plant Pathol. 2010, 39, 477-491. [CrossRef]

40. Crous, P.W.; Groenewald, J.Z.; Shivas, R.G.; Edwards, J.; Seifert, K.A.; Alfenas, A.C.; Alfenas, R.F.; Burgess, T.I.; Carnegie, A.J.; Hardy, G.E.S.; et al. Fungal Planet description sheets: 69-91. Persoonia 2011, 26, 108-156. [CrossRef]

41. Jung, T.; Stukely, M.J.C.; Hardy, G.E.S.; White, D.; Paap, T.; Dunstan, W.A.; Burgess, T.I. Multiple new Phytophthora species from ITS clade 6 associated with natural ecosystems in Australia: Evolutionary and ecological implications. Persoonia 2011, 26, 13-39. [CrossRef]

42. Rea, A.; Burgess, T.I.; Hardy, G.E.S.; Stukely, M.J.C.; Jung, T. Two novel species of Phytophthora associated with episodic dieback of kwongan vegetation of south-west Western Australia. Plant Pathol. 2011, 60, 1055-1068. [CrossRef]

43. Crous, P.W.; Summerell, B.A.; Shivas, R.G.; Burgess, T.I.; Decock, C.A.; Dreyer, L.L.; Granke, L.L.; Guest, D.I.; Hardy, G.E.S.; Hausbeck, M.K.; et al. Fungal Planet description sheets: 107-127. Persoonia 2012, 28, $138-182$. [CrossRef] 
44. Aghighi, S.; Fontanini, L.; Yeoh, P.; Hardy, G.E.S.; Burgess, T.I.; Scott, J.K. A conceptual model to describe the decline of European blackberry (Rubus anglocandicans), a weed of national significance in Australia. Plant Dis. 2014, 98, 580-589. [CrossRef]

45. Crous, P.W.; Wingfield, M.J.; Schumacher, R.K.; Summerell, B.A.; Giraldo, A.; Gené, J.; Guarro, J.; Wanasinghe, D.N.; Hyde, K.D.; Camporesi, E.; et al. Fungal Planet Description Sheets: 281-319. Persoonia 2014, 33, 212-289. [CrossRef] [PubMed]

46. Safaiefarahani, B.; Mostowfizadeh-Ghalamfarsa, R.; Hardy, G.E.S.; Burgess, T.I. Re-evaluation of the Phytophthora cryptogea species complex and the description of a new species, Phytophthora pseudocryptogea sp. nov. Mycol. Prog. 2015, 14, 1-12. [CrossRef]

47. Simamora, A.; Stukely, M.J.C.; Hardy, G.E.S.; Burgess, T.I. Phytophthora boodjera sp. nov., a damping-off pathogen in production nurseries and from urban and natural landscapes, with an update on the status of P. alticola. IMA Fungus 2015, 6, 319-335. [CrossRef]

48. Paap, T.; Croeser, L.; White, D.; Aghighi, S.; Barber, P.A.; Hardy, G.E.S.; Burgess, T.I. Phytophthora versiformis sp nov., a new species from Australia related to P. quercina. Australas. Plant Pathol. 2017, 46, 369-378. [CrossRef]

49. Burgess, T.I.; Simamora, A.; White, D.; Williams, B.; Schwager, M.; Stukely, M.J.C.; Hardy, G.E.S.J. New species from Phytophthora Clade 6a: Evidence for recent radiation. Persoonia 2018, 41,1-17. [CrossRef]

50. Davison, E.M.; Drenth, A.; Kumar, S.; Mack, S.; Mackie, A.E.; McKirdy, S. Pathogens associated with nursery plants imported into Western Australia. Australas. Plant Pathol. 2006, 35, 473-475. [CrossRef]

51. Erwin, D.C.; Ribeiro, O.K. Phytophthora Diseases Worldwide; APS Press: St. Paul, MN, USA, 1996; p. 562.

52. Barber, P.A.; Paap, T.; Burgess, T.I.; Dunstan, W.A.; Hardy, G.E.S. A diverse range of Phytophthora species are associated with dying urban trees in an Australian capital city. Urban For. Urban Gree. 2013, 12, 569-575. [CrossRef]

53. Hüberli, D.; Hardy, G.E.S.; White, D.; Williams, N.; Burgess, T.I. Fishing for Phytophthora from Western Australia's waterways: A distribution and diversity survey. Australas. Plant Pathol. 2013, 42, 251-260. [CrossRef]

54. Hickman, C.J. The red core root disease of the strawberry caused by Phytophthora fragariae n. sp. J. Pomol. Hort. Sci. 1941, 18, 89-118.

55. Themann, K.; Werres, S.; Lüttmann, R.; Diener, H.-A. Observations of Phytophthora spp. in water recirculation systems in commercial hardy ornamental nursery stock. Eur. J. Plant Pathol. 2002, 108, 337-343. [CrossRef]

56. Jung, T.; Chang, T.T.; Bakonyi, J.; Seress, D.; Pérez-Sierra, A.; Yang, X.; Hong, C.; Scanu, B.; Fu, C.H.; Hsueh, K.L.; et al. Diversity of Phytophthora species in natural ecosystems of Taiwan and association with disease symptoms. Plant Pathol. 2016, 66, 194-211. [CrossRef]

57. Eschen, R.; Britton, K.; Brockerhoff, E.; Burgess, T.; Dalley, V.; Epanchin-Niell, R.S.; Gupta, K.; Hardy, G.E.S.; Huang, Y.; Kenis, M.; et al. International variation in phytosanitary legislation and regulations governing importation of live plants. Environ. Sci. Policy 2015, 51, 228-237. [CrossRef]

58. ArborCarbon. Pathogen Sampling \& Mapping Project; Final Report; Prepared for City of Joondalup, June 2016; ArborCarbon: Murdoch, Australia, 2016; p. 83.

59. Burgess, T.I.; McDougall, K.L.; Scott, P.; Hardy, G.E.S.J.; Garnas, J. Predictors of Phytophthora diversity and distribution in natural areas across diverse Australian ecoregions. Ecography 2019, 42, 594-607. [CrossRef]

60. Burgess, T.I. Molecular characterization of natural hybrids formed between five related indigenous clade 6 Phytophthora species. PLoS ONE 2015, 10, e0134225. [CrossRef]

61. Oh, E.; Gryzenhout, M.; Wingfield, B.D.; Wingfield, M.J.; Burgess, T.I. Surveys of soil and water reveal a goldmine of Phytophthora diversity in South African natural ecosystems. IMA Fungus 2013, 4, 123-131. [CrossRef]

62. Panabieres, F.; Ali, G.S.; Allagui, M.B.; Dalio, R.J.; Gudmestad, N.C.; Kuhn, M.L.; Guha Roy, S.; Schena, L.; Zampounis, A. Phytophthora nicotianae diseases worldwide: New knowledge of a long-recognised pathogen. Phytopathol. Mediterr. 2016, 55, 20-40.

63. Lowe, S.; Browne, M.; Boudjelas, S.; De Poortner, M. One-hundred of the world's worst invasive alien species. In A Selection from the Global Invasive Species Database; The Invasive Species Specialist Group, International Union for Conservation of Nature (IUCN): Gland, Switzerland, 2000.

64. Burgess, T.I.; Scott, J.K.; McDougall, K.L.; Stukely, M.J.C.; Crane, C.; Dunstan, W.A.; Brigg, F.; Andjic, V.; White, D.; Rudman, T.; et al. Current and projected global distribution of Phytophthora cinnamomi, one of the world's worst plant pathogens. Glob. Chang. Biol. 2017, 23, 1661-1674. [CrossRef] [PubMed] 
65. Migliorini, D.; Khdiar, M.Y.; Rodríguez Padrón, C.; Vivas, M.; Barber, P.A.; Hardy, G.E.S.; Burgess, T.I. Extending the host range of Phytophthora multivora, a pathogen of woody plants in horticulture, nurseries, urban environments and natural ecosystems. Urban For. Urban Gree. 2019, 46, e12646. [CrossRef]

66. Nesbitt, H.J.; Malajczuk, N.; Glenn, A.R. Effect of organic matteron the survival of Phytophthora cinnamomi Rands in soil. Soil Biol. Biochem. 1979, 11, 133-136. [CrossRef]

67. McCarren, K.L.; McComb, J.A.; Shearer, B.L.; Hardy, G.E.S. The role of chlamydospores of Phytophthora cinnamomi-A review. Australas. Plant Pathol. 2005, 34, 333-338. [CrossRef]

68. Redondo, M.A.; Boberg, J.; Stenlid, J.; Oliva, J. Functional traits associated with the establishment of introduced Phytophthora spp. in Swedish forests. J. Appl. Ecol. 2018, 55, 1538-1552. [CrossRef]

(C) 2020 by the authors. Licensee MDPI, Basel, Switzerland. This article is an open access article distributed under the terms and conditions of the Creative Commons Attribution (CC BY) license (http://creativecommons.org/licenses/by/4.0/). 